https://doi.org/10.18485/iipe_60nam.2021.ch19

\title{
60 YEARS AFTER BELGRADE: PASSION, REFLECTION AND CHALLENGES FROM INDONESIAN PERSPECTIVE
}

\author{
M. Faishal AMINUDDIN ${ }^{1}$
}

\begin{abstract}
The Non-Aligned Movement (NAM) has developed into a large movement in terms of the number of members. But after 60 years of its birth and existence, to what extent does this movement have real significance and benefit all its members? This article proposes to review historically the contribution, problems, and prospects of Indonesia's interaction within the NAM. Three framework arguments will be explored more deeply. First, in the post-Cold War, the NAM has adopted the model called "ceremonial leadership" that is rotated from one country to another. This, however, did not bring much progress towards the ratification of the values and principles of Belgrade that can be formulated and implemented massively. Second, cooperative relationships that involve individual socio-economic mobility run very slowly and are still limited by technical problems. As a result, the transfer of research, science, and technology is not able to contribute to strengthening the economic and industrial structure amongst all members. Indeed, there has been progress despite discussions and interpretations of the changing world constellation followed by the information-sharing policies. From an Indonesian case and perspective, this article provides a critical note of the future of the NAM which is nothing more than an organisation of friendship.
\end{abstract}

Key words: The Non-Aligned Movement, Indonesia, post-Cold War, challenges.

${ }^{1}$ Vice Dean of the Faculty of Social and Political Sciences, University Brawijaya, Indonesia.

E-mail: mfaishal@ub.ac.id 


\section{Introduction}

When I just graduated with a degree in history, it was the end of 2004, and various narratives about nationalism, the story of Sukarno's greatness and role in international progress, the Bandung Conference, and the establishment of the NAM in Belgrade began to stir in debates in the Indonesian public sphere. At the same time, Indonesia was a country that had an authoritarian military regime only a few years ago and was just stepping on the path to democracy. As a "new historian", the topic of the debate sparked curiosity while diving into the past. However, tracing historical Indonesia's contribution and progress, both the government or various other organisations and individuals in the NAM is still very difficult. Access to information sources, although improving, is still limited. In that year, I wondered if the NAM was still relevant. (Faishal, 2004). It could be that the founders of the NAM are only a group of daytime dreamers (Ajami, 1980). Nevertheless, I still have an optimistic view, which is probably the result of the impressions I gained reading the speech of the President of South Africa, Thabo Mbeki, at the AASROC Conference in August 2004. He said that the concrete agenda that the Asia-Africa region should immediately focus on should be concentrated on three things: poverty alleviation in order to catch up with the economy, increase of security cooperation in the face of terrorism and encouragement of the restructuring of global forces (Mbeki, 2004). When I look back at the Belgrade Conference of September 1961, I summarise two key messages: to protect peace and reject colonialism and imperialism. This issue was still on the main agenda at the NAM conference in Cairo in 1964. In the 1960s, Indonesia was one of the founding members with a major role of Sukarno after the Bandung 1955. Of course, as a newly independent country, Indonesia had strong reasons to be actively involved in the international stage to build solidarity among post-colonial nations to have a strong spirit to end this practice. A major campaign through international organisations is necessary as other member countries are in a marginal position politically. Indonesia is also economically weak; the NAM has become quite an effective tool in building diplomacy, in politics, culture, and economics. I observed that the Bandung 1955 was a milestone for affirming Indonesia's existence in campaigning for anti-colonialism and international sovereignty. Even though, it must be admitted that these claims are not real, pseudo, and one-sided because many things do not match between the desires and the operation of state machines to implement the various values and principles campaigned (Rubinstein, 1970). At that time, being 
part of Europe, Yugoslavia was not yet a part of the Asian-African solidarity. However, after Tito visited India, Burma, Egypt, and Ethiopia from December 1955 to January 1956, he felt the need to build cooperation within the framework of "creative coexistence" (Jerkovic, 1956). At its climax, the seventh Congress of the Yugoslav Communist League in March 1958 affirmed his decision not to join the Soviet bloc and to anchor his choice to a non-aligned foreign policy (Rubinstein, 1970; p. 76). Marshal Josip Broz dared to leave the Soviet bloc and build new international cooperation through the NAM which was considered a subaltern in the international system (Miskovic et al., 2014). This decision then expanded the international solidarity network which was not only limited to the AsiaAfrica region, but opened opportunities for countries in any region that agreed on the "non-aligned" principle. 60 years after Belgrade, in terms of quantity, the number of members is getting bigger (around 120 countries). However, the NAM solidarity is not well-institutionalised. We still see sharp disputes, military conflicts, human rights violations, poverty, and even serious ecological damage, which the NAM as an organisation has not been able to fully resolve. Cooperation in the economic sector has not been seen to be mutually beneficial. Each country member still has a high level of dependence on rich countries and maintains a stronger intensity of multilateral cooperation with them. This is what causes bias perspective when great power countries that have much greater power impose their will. Through this article, I see the macro narrative of the NAM in global politics by comparing the existence of the NAM from an Indonesian perspective. How is the portrait of the history and transformation of the NAM from the point of my passion, being an Indonesian who touches, observes and studies it? Indonesia's experience within the NAM reflects many things. The most important of these is that each NAM member country has a sovereign right to make decisions. The NAM should be used to support national programmes from minimum to maximum.

\section{The NAM in the Eyes of an Indonesian}

I share three periodizations of the NAM's narrative among Indonesian audiences. First, the 1955-1965 period became an era of euphoria in which Indonesian resistance to what was known as "neocolonialism" or Nekolim could be understood by the general public. Almost all political forces in this newly independent country warmly welcomed Sukarno's initiative to involve Indonesia in the vortex of the global movement. It was the campaign against Nekolim that positioned Indonesia as a "Nefo" (New Emerging Forces) 
who dared to face Western giants such as America and its Western allies. The campaign was supported by various constructions of high-cost lighthouse projects in the capital, Jakarta. Of course, the political, religious, and cultural elites did not support the campaign with a blank check. It is noted that they were involved in various meetings of Asia-Africa and the NAM in the fields of youth, religious organisations to the emancipation of women. The second is the period of the New Order military regime which has been in power since 1967 but effectively starting in 1970 and falling in 1998. In this era, the state took an absolute role as an authoritative source in socialising the NAM through the official government media and ministries. Practically, the NAM narrative was copyright and became the exclusive right of the government, which created a massive image that Indonesia had succeeded in continuing the relay as an important player. Especially when in 1992-1995 Indonesia held the leadership position. The third was the period after 1998. The democratic era provided wider space for synergy development between the government, the private sector, and the public to design and execute various foreign collaborations to accelerate the progress of cooperation. During this period, the task force team formed by the government began to organise the division of tasks in the Ministry of Foreign Affairs to develop aspects of diplomacy and international spokespersons. Then the Ministry of National and Development Planning was the executor of technical cooperation as a follow-up to diplomatic agreements with other countries. In the first period, Indonesia's entry as one of the founding members certainly provided benefits. The image of being a champion of anti-colonialism led to an increase in Indonesia's bargaining position against the domination of the United States in Southeast Asia. Simultaneously, it could also build a strategic partnership with the Soviet Union. This made it easier for Indonesia to get access to weapons from both parties which were used to overcome the various separatist conflicts that had sprung up in the country from 1950 to the 1960s. Even though Indonesia was considered by the Soviets a non-socialist country but a nationalist democracy, they considered Indonesia a country that should be embraced. Bilateral relations were strengthened by Sukarno's mutual visits to the Soviet Union in 1956 and Khrushchev's to Indonesia in 1960. The relationship became more intimate when US President Dwight Eisenhower refused the Indonesian loan proposal in 1956. This served as a starting point for Indonesia to get closer to the Soviets. Then Khrushchev offered a loan of 100 million dollars with 2.5 per cent interest. A new \$ 250 million loan was subsequently taken. With this loan, Indonesia financed various lighthouse projects, national strategic industries, including agriculture, energy, 
infrastructure and the military. At the same time, technology transfer was performed this way (Boden, 2008: p. 115-118). The Soviet support was not necessarily due to the orientation of Sukarno's foreign policy which was closer to them. An important factor that must be noted was the large support of the Indonesian Communist Party (PKI) for the government. The PKI maintained a strong network with its Soviet counterparts and became a political guarantee that the Soviet interests in Indonesian politics were wellrepresented and trusted. This meant that the PKI could also give its commitment to encourage Sukarno to build strategic partnerships with the Soviets rather than the US or the Western bloc. In 1965, there were changes in the domestic political situation that led to the fall of Sukarno in 1966 and drastically changed the course of foreign policy. The strategic projects of the long-term Soviet loans requiring an average of 10-15 years of development also ended. By early 1965, only three of the 27 projects financed by the Soviet foreign debt had been completed. Even though they accounted for 10 per cent of total Soviet aid projects in Asia, the number that could be completed was the lowest, only four per cent. The contracts from 1956-1960 indeed only regulated economic and technical cooperation without any detailed conditions for spending money and supervision (Ibid, 119). The needs of the Sukarno regime to finance the operational needs of this newly independent state were almost entirely dependent on foreign loans and assistance. In addition, the parliamentary democracy model did not provide stability for the government. The protracted political conflict in the parliament between various parties and political factions was added to the problem of armed rebellion in the regions against Jakarta. As a result, supervision of debt funds was low and vulnerable to be allocated for other financing outside of the agreement. The vulnerability of budget misuse, either from own income or foreign debt, was evidenced by the emergence of major corruption cases, for example, the construction of the Conefo tower building in Jakarta, which was financed by loans from the United Arab Emirates and the People's Republic of China (PRC). Apart from accommodating loan funds from the Soviets, Indonesia also received a lot of support and economic assistance from the PRC, where one of the diplomatic supports was Indonesia's claim to Papua. Even though in the Papua dispute, Indonesia could also get support from the US. In June 1961, Sukarno visited China and was praised by President Liu Shaoqi for his role in promoting the "great project of Friendship Bridge between China and Indonesia." In addition, the slumping of domestic economic conditions has affected the country's already very small income. The reason for that was the fact that foreign debt was also used for short-term consumer financing. 
During the Suharto military regime, the NAM was used as a means of garnering diplomatic support for the benefit of regime consolidation at home. At the same time, Indonesia needed a foreign policy strategy that was mutually beneficial. Indonesia has received support for its strategic interests in the UN forums. From 1970 to 1980, Indonesia was able to build international cooperation in strengthening food security, especially with African countries. In addition, trade diplomacy involved the entry of investment in natural resource management, modernisation of agricultural infrastructure and technology. Also, the issue of the annexation of TimorLeste did not appear to be detrimental to Indonesia. From the 1990s to the present, Indonesia has received wider space, not only for its commodity markets in global trade, but also for efforts to transfer technology and exchange educational and cultural missions. The foreign policy of the Suharto regime was influenced by two important things.

First, foreign policy was close to that of the United States during the Cold War. The US interest in stemming the communist movement has required strong military support. Indonesia's proximity to the Western bloc was followed by the opening of its doors to foreign investment, mining concessions, and all infrastructures for the modernisation of weapons with US products. From economic liberalisation, Indonesia got a lot of financial income to drive its development. The political situation was also increasingly stable because the government operated in an authoritarian model where iron-fisted policies of the state could be implemented without resistance. Foreign loans could be controlled, and the focus of development was agriculture, education, and access to health as basic services for the community. This focus on improving basic services replaced the lighthouse project based on the prestige of the Sukarno era. The success in food security has given Indonesia greater confidence to campaign for an end to hunger and the global food crisis, especially for countries in Africa.

Second, the change in political direction caused by the end of the Cold War, the collapse of the Soviet Union, and the Balkanization caused the world to move to multipolarity. At this point, the NAM was no longer considered solid. The multipolar world made each member country calculate the cost and benefit of their relationship with potential powers other than the US. During the US invasion of Iraq in 1991, the NAM was no longer solid as it was when it was faced with a choice of resolutions and arms emblems in the Yugoslavian conflict. In this condition, China, which started to emerge as a world power, began to enter as an observer and was interested in consolidating its network with the NAM (Morphet, 1993). In 
the following period, they played a key role in bringing about a new balance with their economic and military power. The large investment and dependence of developing countries in Africa have ultimately strengthened China's dominance in the region.

The Indonesian government sees changes in the global constellation, bringing new perspectives to the direction of the NAM cooperation which focuses on two things: the backdrop of rapid globalisation and deepening interdependence. The globalisation that is running fast and the world becoming borderless must be welcomed with open arms. Of course, the economic projections are designed based on the acceptance of the freemarket system. The building of cooperation is not only the political aspect because interdependence is translated as "free will" of the state to cooperate with other countries in accordance with the agenda, issues, pressures, and the benefits obtained. Indonesia considers that strengthening economic cooperation, North-South dialogue, South-South cooperation, and reducing foreign debt are important international campaigns (Soeharto, 1995). The Indonesian campaign asks developed countries to set aside 0.7 per cent of GDP and give it to developing countries under various schemes, even though the then realisation of GDP was only 0.37 per cent. With limited funding, Indonesia sees solidarity as a form of concern. No matter how small, efforts to help countries in need must be made. Wealthy small countries such as the Kingdom of Brunei were asked for support in overcoming food shortages in Africa. Brunei financed a tour of a group of farmers from Africa to Indonesia to see traditional agricultural management practices firsthand and to learn about the role of farmers. At the $2019 \mathrm{Baku}$ Summit, Indonesia conveyed important aspirations related to making more concrete cooperation and exemplifying South-South Technical Cooperation (SSTC) which already had significant results. Technical cooperation has direct benefit value, not only increasing capacity, sharing experiences, but also accelerating mobility among people. Of the many high-level meetings, declarations, political speeches, joint statements in other UN and international forums, political apathy to interfere in the domestic affairs of each NAM member is still maintained. The "heroic" event that was played repeatedly on the national television at that time was Suharto's visit to Zagreb and Sarajevo. He is considered brave because of the war situation that was very dangerous for the head of state to be present there. Even though the message was passive, it assumed that no other party could resolve the conflict other than their leaders. On the other hand, Indonesia has the uniqueness of being a NAM country with the largest Muslim population. This resulted in opinions that must be consistent in global issues 
involving religion and the Islamic world in general. On the issue of Palestine, Indonesia hardly provided space for dialogue, even though President Wahid tried to initiate it in the 2000s. The same thing was emphasised again as an important agenda at the 2012 Tehran Summit, the Palestine Solidarity Declaration.

From the post-Cold War transformation, multilateral cooperation is based on national interests, especially economic interests. The rise of China as a world economic power is, in turn, currently seen by Indonesia as an alternative. Trade and economic cooperation are continuously forged and strengthened. At the same time, the tension in the South China Sea, which is always high, does not make it an important issue for resistance on the grounds of national sovereignty. Various countries were faced with domestic problems such as civil conflicts, separatism, and economic instability. In a multipolar world's political structure, each country has the ability to make more choices. Indonesia's position has changed. From 1950 to the 1960s, Indonesia's foreign policy was free and active. This means that Indonesia was free in determining the choice of partners for cooperation but active in pursuing world peace. This doctrine lasted until the end of the 1990s and experienced a shift during President Yudhoyono from 2004-2014 to become "thousands of friends, zero enemies" which means that all political risks that will be faced by Indonesia in the global political arena should be minimised wherever possible. In general, since 1970, the doctrine of foreign policy has been restored to conform to the original conception of Vice President Hatta in 1948, namely a commitment to independence and an active foreign policy (Leifer, 1973). After the 1990s, doctrines of foreign policy can be called passive pragmatism (Sukma, 1995). This is a portrait of other NAM countries occupying positions towards important world powers (Western Europe, the US, Russia and China).

\section{Challenges and the Future of the Nam}

The relevance of the existence of the NAM has long been questioned. Apathy for its future has emerged since the late 1960s. The NAM is considered a collection of speeches by heads of state and declarations that are not followed by practical action, where the procedures are complicated and often tedious so that they are inefficient with unclear results (Graham, 1980; Kochan, 1972). To that end, there are calls for organisation reform and policy changes. Even if necessary, replace the word "non-alignment" with the Southern Solidarity Movement (Keethaponcalan, 2016: p. 14). But in fact, 
the membership is still standing and growing in terms of quantity. Many countries enter as observers and have an interest. In the context of multilateralism, the existence of the NAM is no less important than before (Jazic, 2005). Politically, the NAM will always be the vehicle of its members to fulfil their national interests. It depends on domestic political contestation. India, for example, tended to be America's friend in the Nehru era. Then the relationship strengthened in the era of Indira Gandhi where the principles of the NAM, which were in line with Indian interests, were only adhered to. In such a position, India will remain a part of the NAM based on a more symbiotic bond than consistently upholding the principles (Rauch, 2008: $p$. 31-33; Mohan 2003: p. 46). In the Second South Summit of the G-77 which produced the Doha Plan in 2005, it was known that economic development efforts through UN multilateral control had the potential to create separate problems for South-South cooperation. International trade, monetary, and banking instruments cannot simply and sustainably provide their support to developing countries. Multilateralism is ultimately a key phrase that requires an explanation of the value and rule of the game in the NAM. An important criticism that needs to be addressed in this regard is that the overreliance on multilateralism as a tool to strengthen the political economy position of developing countries has failed. The reason is that developed countries also have stronger ties and are supported by an equal position of mutual need. For the multilateralism which is built to have an impact and benefit, it is necessary to carry out domestic reforms in the NAM countries to make it compatible with international values and then talk about institutional reform (Strydom, 2007: p. 44). In this condition, it is necessary to strengthen the North-South dialogue or better known as the triangular cooperation model. In making its contribution to the NAM, Indonesia manages cooperation affairs through its foreign ministry. This ministry is actively participating in various events both inside the UN and outside and is involved in lobbying and diplomacy for the delivery of technical assistance between countries. Meanwhile, other routine contributions are carried out in the annual cooperation program of the Ministry of Foreign Affairs and its diplomatic network. To the Indonesian leadership, the message conveyed at the Jakarta Summit in early September 1992 emphasised the transfer of technology and experience in the fields of food security, population, and foreign debt reduction (Jakarta Declaration, 1992). The Indonesian government was paying special attention. Therefore, it formed a task force team led by Nana Sutresna, an expert team led by Economist Widjojo Nitisastro, which coordinated strengthening effective cooperation with the full involvement of all president-men. They were 
moving to reach out for cooperation with partner countries through Indonesian embassies in these countries. The team was an important figure around President Suharto, who was thought to be able to immediately conceptualise the programme up to the level of programme execution so that organisational obstacles at the ministerial level could be overcome. For Indonesia, concrete roles and contributions could be made after the establishment of the Centre for South-South Technical Cooperation (CSSTC) of the NAM in 2001, which acted to expand and accelerate the transfer of light technology and various advances in microeconomic tools. This institution could be called the most concrete manifestation of development cooperation within the NAM. In the era of Indonesian leadership in 19921995, economic cooperation was described as intensive South-South cooperation as well as redefining the NAM vision according to the 1995 Cartagena Declaration. The efforts included cooperation in the field of poverty alleviation, strengthening small businesses, using IT technology. Apart from that, Indonesia also has the opportunity to provide the Developing Countries Partnership (KNB) scholarship scheme for the NAM members, especially those from poor countries.

The SSTC is a tool for Indonesian cooperation with Asian-African countries which then develops more broadly in South-South and NorthSouth cooperation. Indonesia's interests are no longer merely diplomatic matters, but how mutually beneficial cooperation can be carried out. Political value in the NAM is considered final where each country may not interfere in the domestic affairs of other member countries. Like Suharto, who managed the country in an authoritarian model, or also many other NAM countries where democracy is not something that should be well-established as a more just political system. The NAM was eventually reduced to a collaboration that focused on economic development affairs with common welfare goals. The 1992 Jakarta Summit became Indonesia's first postSukarno international stage where the opportunity was won because Nicaragua withdrew from its candidacy to host the 10th Summit (Syatauw, 1993). The implementation of the summit then underlies the strategy and implementation of Indonesian economic and technical cooperation in other NAM member countries.

South-South cooperation is also making progress as the NAM itself is expanding and intensifying various models of cooperation. The existence of Technical Cooperation for Developing Countries (TSDC) as a catalyst in regional cooperation then plays an important role before a permanent institution is formed. In 1995, after the NAM ministerial meeting, Indonesia 
proposed the idea of establishing a South-South Technical Cooperation Centre as the centre for all cooperation activities, evaluation, and reporting of cooperation. However, until 2004, each ministry was still running the cooperation program separately and was no longer connected as a series of coordination. This is why the amount of contribution, the direction of foreign policy, and the diplomatic targets of the cooperation cannot be measured. In 2006, the Ministry of Foreign Affairs had a technical cooperation directorate to ensure that the field of cooperation was more organised, not only limited to carrying out solidarity and mutually beneficial cooperation, but also in the context of supporting diplomacy. In that year, Indonesia has allocated 49.8 million USD to finance 700 cooperation programmes involving thousands of participants in 91 developing countries.

In the latest progress, there are two key words to explain Indonesia's hopes for the NAM. First, as stated by President Joko Widodo, it is important to translate the meaning of political solidarity into more concrete collaboration (Pinandita, 2020). This applies not only in the context of the accessibility of developing countries to vaccines and treatment to end the Covid-19 pandemic. As can be seen, access to better vaccines is only dominated by rich countries, and most of them are competing to save and appear selfish with what is called "vaccine nationalism". Second, in a speech, the Minister of Foreign Affairs, Retno Marsudi, emphasised strengthening the spirit of multilateral cooperation, regulating the global economy through strong and balanced partnerships, and increasing internal cooperation through concrete collaboration. Thus the NAM will not become just a "talk shop" organisation (Paskalis, 2016). The concrete collaboration that Indonesia wants in economic cooperation and vaccine procurement has received a wide response from China, which can take advantage of the pandemic to position itself as a "helper god" by giving developing countries access to its vaccine production. The mentioning of a "talk shop" organisation also has implications for the direction of Indonesia's foreign policy which seems to have a stance that the NAM has not provided clear benefits for the needs of its member countries.

\section{Conclusions}

There are three urgent things to do in clarifying the future of the NAM. First, eliminating institutional problems by changing the ceremonial leadership model as has happened so far. The NAM needs to be a strong multilateral collaboration with a semi-permanent at a minimum on its 
organisational system and infrastructure. Second, accelerating the pace of social, cultural and educational, and technological science mobility among the NAM members. Increasing the number of study scholarships, cooperation between universities, transfer of technology between strategic institutions, and ensuring high mobility can be done when each country opens its borders. Third, the NAM must have a global policy platform derived from the principles that are continuously updated according to the times. Without this platform, each member country will define its national interest which is often counterproductive to the interest of solidarity among the NAM members.

\section{References}

Ajami, F. (1980). The fate of nonalignment. Foreign Affairs, 59(2), pp.366-385.

Boden, R. (2008). Cold War Economics: Soviet Aid to Indonesia. Journal of Cold War Studies, 10(3), pp.110-128.

Faishal, M. (2004). Masa depan politik GNB, The Political Future of NAM, Kompas, 16 December.

Graham, J.A. (1980). The non-aligned movement after the Havana Summit. Journal of International Affairs, pp.153-160.

Jakarta Declaration. (1992). 10thSummit Conference of Heads of State or Government of the Non-Aligned Movement, Jakarta, Indonesia 1-6 September, retrieved from http://cns.miis.edu/nam/documents/ Official_Document/10th_Summit_FD_Jakarta_Declaration_1992_Whol e.pdf

Jazić, Ž. (2005). The Non-Aligned Movement yesterday and today-in the process of globalization: critical view. Croatian International Relations Review, 11(38/39), pp.59-66.

Keethaponcalan, S.I. (2016). Reshaping the Non-Aligned Movement: challenges and vision. Bandung, 3(1), pp. 1-14.

Kochan, R. (1972). Changing emphasis in the non-aligned movement. The World Today, 28(11), pp.501-508.

Leifer, M. (1973). Continuity and change in Indonesian foreign policy. Asian Affairs, 4(2), pp. 173-180.

Mbeki, T. (2004). Opening Remarks by the President of the Republic of South Africa at the Non-Aligned Movement Ministerial Conference, Durban, 
19 August. Retrieved from http:/ / www.dirco.gov.za/docs/speeches/ 2004/mbek0820.htm

Mišković, N., Fischer-Tiné, H., \& Boškovska, N. (2014). Delhi-BandungBelgrade: Non-Alignment between Afro-Asian Solidarity and the Cold War.

Mohan, C.R. (2003). Crossing the Rubicon: The Shaping of India's New. Foreign Policy, 120.

Morphet, S. (1993). The Non-Aligned in 'The New World Order': The Jakarta Summit, September 1992. International Relations, 11(4), pp.359-380.

Paskalis, Y. (2016). Indonesia Calls Non-Aligned Countries to Take Actions, Tempo.Co. retrieved from: https://en.tempo.co/read/804679/ indonesia-calls-non-aligned-countries-to-take-actions

Pinandita, A. (2020). COVID-19: Jokowi calls on NAM nations to boost solidarity in battle against 'mutual enemy, The Jakarta Post, retrieved from: https://www.thejakartapost.com/news/2020/05/05/covid-19jokowi-calls-on-nam-nations-to-boost-solidarityin-battle-againstmutualenemy.html.

Rauch, C. (2008). Farewell Non-Alignment? Constancy and change of foreign policy in post-colonial India, DEU. 85, p. 40).

Rubinstein, A.Z. (1970). Yugoslavia and the nonaligned world. Princeton University Press.

Soeharto, H.M. (1995). Speech at $11^{\text {th }}$ conference of Head of states and government NAM, Cartagena, Colombia, October, 18.

Strydom, H. (2007). The Non-Aligned Movement and the reform of International relations. Max Planck Yearbook of United Nations Law Online, 11(1), pp. 1-46.

Sukma, R. (1995). The evolution of Indonesia's foreign policy: an Indonesian view. Asian Survey, 35(3), pp. 304-315.

Syatauw, J.J.G. (1993). The Non-Aligned Movement at the Crossroads - The Jakarta Summit Adapting to the Post-Cold War Era. In Asian Yearbook of International Law, 3, pp. 129-162. 